\title{
EFFECTS OF ENVIRONMENTAL TEMPERATURE AND MEMBRANE FEEDING SOLUTIONS OF PURIFIED OOKINETES ON THE SPOROGONIC DEVELOPMENT OF PLASMODIUM BERGHEI
}

\author{
Kenyichi Yano*, Karl Maramorosch and Albina Kozlowska \\ Received April 27 1989/Accepted August 181989
}

\begin{abstract}
When Anopheles stephensi infected with Plasmodium berghei by bite were kept at $21^{\circ} \mathrm{C}$ in darkness, degenerative changes occurred in $33.8 \%$ of oocysts, as contrasted to $1.5 \%$ of such changes in mosquitoes kept at $21^{\circ} \mathrm{C}$ with 12 -hr light period. Temperature shift of infected mosquitoes from $21^{\circ} \mathrm{C}$ for $24 \mathrm{hr}$ to $25^{\circ} \mathrm{C}$ and $28^{\circ} \mathrm{C}$ increased the degeneration rate of oocysts to $87.8 \%$ and $85.8 \%$, respectively, and inhibited oocysts maturation. $P$. berghei ookinetes were cultured from gametocytes of infected hamster blood and purified by discontinuous Percoll gradient, using the modified procedure described by Munderloh and Kurtti (1987). Suspensions of purified ookinetes $\left(1 \times 10^{6} / \mathrm{m} l\right)$ fed through membrane feeders permitted stable infection of $A$. stephensi. Mosquitoes fed purified ookinetes in phosphate buffered saline (PBS) and then maintained only with sugar, were able to produce infective sporozoites. Fetal bovine serum, mammalian cell medium F-12, and hamster red blood cell, added to PBS, improved infectivity of ookinetes to mosquitoes and decreased degenerative changes during oocyst development. The system of feeding purified ookinetes in simple chemical solution, PBS, would help to gain more information about the transformation of ookinetes to oocysts.
\end{abstract}

\section{INTRODUCTION}

Most of the life cycle of the rodent malaria parasite, Plasmodium berghei can be studied in in vitro culture systems: exoerythrocytic cycle in liver (Hollindale et al., 1983), erythrocytic cycle in blood (Janse et al., 1984), gametocytogenesis (Mons et al., 1985) and ookinete formation (Weiss and Vanderberg, 1977; Janse et al., 1985a, b; Sinden et al., 1985).

The transformation of ookinetes to oocysts and the development of oocysts have not yet been studied in an in vitro system. Progress in cultivation of ookinetes and their development to mature oocysts has been hampered by the lack of information on the biophysiological conditions of sporogony in anopheline mosquitoes. We report the effect of environmental temperature and darkness on sporogonic development of infected Anopheles stephensi and the nourishing effect of the feeding solution of purified $P$. berghei ookinetes as determined by examination of the number and degenerative changes of oocysts in mosquito midguts.

Department of Entomology and Economic Zoology, Cook College, Rutgers University, New Brunswick, New Jersey 08903

* Present address; Department of Protozoology, Research Institute for Microbial Diseases, Osaka University, Suita, Osaka 565, Japan 


\section{MATERIALS AND METHODS}

Parasites and hosts:

The Plasmodium berghei (strain ANKA) - Anopheles stephensi-golden hamster (Mesocriecetus auratus) complex was maintained as described by Vanderberg et al. (1968), and used for experiments.

Usually hamsters, 17 to 24 days old, were inoculated with $P$. berghei. Older hamsters than these were injected with phenylhydrazine $\mathrm{HCl}(100 \mathrm{mg} / \mathrm{kg})$ four days before infection (Janse et al., 1985b).

For infection, 40-50 female mosquitoes 3-7 days old, were collected from a stock colony into small mosquito cages, using disposable $350 \mathrm{~m} l$ plastic caps. Infected mosquitoes were maintained at $21^{\circ} \mathrm{C}$ with a daily cycle of $12 \mathrm{hr}$ of light and darkness on $5 \%$ sucrose provided on dental cotton roll.

Media:

The ookinete culture medium consisted of Ham's F-12 medium (GIBCO) without $\mathrm{NaHCO}_{3}$, supplemented with $10 \%$ heat-inactivated fetal bovine serum (FBS: GIBCO), $25 \mathrm{mM}$ BICINE. The $\mathrm{pH}$ of the medium was adjusted to 8.0 with $1 \mathrm{~N} \mathrm{NaOH}$. The culture medium F-12, supplemented with $10 \%$ FBS, $25 \mathrm{mM}$ HEPES and $0.2 \% \mathrm{NaHCO}_{3}$, and adjusted to $\mathrm{pH}$ 7.3 with $1 \mathrm{~N} \mathrm{NaOH}$ (washing medium), was used for washing ookinetes, for dissecting mosquito midguts and for diluting blood and $90 \%$ Percoll.

Culture and harvest of ookinetes:

Ookinetes were cultured and harvested according to the modified procedure described by Munderloh and Kurtti (1987). One $\mathrm{m} l$ of the parasitized blood containing approximately 15 units of heparine $/ \mathrm{m} l$ was inoculated into petri dishes ( $100 \mathrm{~mm}$ diameter) (Falcon) containing $10 \mathrm{~m} l$ of ookinete culture medium and incubated at $21^{\circ} \mathrm{C}$ for $20-22 \mathrm{hr}$ to develop ookinetes.

Purification of ookinetes:

Isotonic $90 \%$ Percoll was prepared by adding 1 volume of $10 \times$ concentrated medium 199 (GIBCO) to 9 volumes Percoll (Sigma). This was further diluted to $45 \%$ and $36 \%$ with washing medium. The above cultures were collected into centrifuge tubes in an ice bath and centrifuged at $150 \times \mathrm{g}$ for $8 \mathrm{~min}$ at $4^{\circ} \mathrm{C}$. Both supernatant and upper greyish layer on the sediment were used to collect ookinetes. The supernatants were centrifuged at $175 \times g$ for 10 min and the sediment were resuspended in $5 \mathrm{~m} l$ of $36 \%$ Percoll. The upper greyish layer of the sediment were collected into centrifuge tubes containing $10 \mathrm{~m} l$ of washing medium and also centrifuged at $175 \times g$ for $10 \mathrm{~min}$. Then again, the upper greyish layers were carefully collected and resuspended in 36\% Percoll. Both 36\% Percoll suspensions were separately overlayed on $5 \mathrm{~m} l$ of $45 \%$ Percoll and then $3 \mathrm{~m} l$ of washing medium was overlayed on each suspension. The preparations were spun at $150 \times g$ for $5 \mathrm{~min}$ and then for another $12 \mathrm{~min}$ at $700 \times g$. The interfaces between the $45 \%$ and $36 \%$ Percoll were removed with a Pasteur pipet, and the number of ookinetes and contaminated red blood cells (RBC) were counted in a hemocytometer. Samples containing RBC fewer than 30 per ookinete were washed once and resuspended with described membrane feeding solutions, then used for feeding. 
Effect of environmental temperature and darkness on sporogonic development:

Mosquitoes in 2 small cages were allowed to feed on an infected hamster for $10 \mathrm{~min}$ at $21^{\circ} \mathrm{C}$ and then mosquitoes in other 2 cages were fed on the same hamster for $20 \mathrm{~min}$ at $21^{\circ} \mathrm{C}$.

After acquisition of the infected blood, mosquitoes in one cage was kept at $21^{\circ} \mathrm{C}$ with 12-hr light period as a standard control. Some cages were kept at $21^{\circ} \mathrm{C}$ for $24 \mathrm{hr}$ and then kept at $25^{\circ} \mathrm{C}$ or $28^{\circ} \mathrm{C}$ with $12-\mathrm{hr}$ light period, respectively. Other cages were kept at $28^{\circ} \mathrm{C}$ with $12-\mathrm{hr}$ light period or at $21^{\circ} \mathrm{C}$ in darkness throughout the experiment.

Infected mosquitoes were dissected on day 11 post infection (PI) (experiment 1) and day 12 PI (experiment 2 and 3 ). The dissected midguts were examined with an inverted phasecontrast microscope at $360 \times$ magnification for the presence of oocysts.

Sporozoite infections of hamsters were carried out on day $15 \mathrm{PI}$ in experiment 1 and 2, and day $17 \mathrm{PI}$ in experiment 3 . In the experiment 1 and 2, anesthetized hamster pups were placed on the top of the mosquito cages. The infected mosquitoes were allowed to feed through the nylon net of the cage on the underside of the hamster for $20 \mathrm{~min}$. In the experiment 3 , each mosquito was cut in half at the junction of the thorax and abdomen. The head-thoraxes of mosquitoes containing mature oocysts in the abdomen were kept in an Eppendolf containing the washing medium, 0.2 to $0.5 \mathrm{~m} l$ in an ice bath according to the number of mosquitoes dissected, and crashed with a round head of a spatula, after all mosquitoes were examined for the presence of oocysts. The suspension was centrifuged at $150 \times g$ for $2 \mathrm{~min}$ to remove the large mosquito debris. When the number of sporozoites in the supernatant could be counted in a hemocytometer, $1 \times 10^{3}$ sporozoites were used for infection of a hamster by intracardial inoculation carried out under sodium pentobarbital anesthesia.

Table 1 Effects of environmental temperature and darkness on sporogonic development of Plasmodium berghei

\begin{tabular}{|c|c|c|c|c|c|}
\hline $\begin{array}{c}\text { Environmental } \\
\text { condition }^{\text {a) }}\end{array}$ & $\begin{array}{c}\text { No. of } \\
\text { experiment }\end{array}$ & $\begin{array}{c}\% \text { Infected } \\
\text { (No. examined) }\end{array}$ & $\begin{array}{l}\text { No. of oocysts/ } \\
\text { infected } \\
\text { mosquito } \pm \mathrm{SD}\end{array}$ & $\begin{array}{l}\text { Degeneration } \\
\text { rate }(\%) \\
\text { of oocysts } \\
\text { (average) }\end{array}$ & $\begin{array}{c}\text { Infectivity of } \\
\text { sporozoites } \\
\text { (No. of mosquitoes } \\
\text { used) }\end{array}$ \\
\hline \multirow[t]{3}{*}{$21^{\circ} \mathrm{C}$} & 1 & 100.0 & $30.2 \pm 33.9$ & 0 & n.c. ${ }^{\text {b) }}$ \\
\hline & 2 & 44.0 & $16.4 \pm 42.3$ & 3.1 & $+(18)$ \\
\hline & 3 & 100.0 & $48.1 \pm 25.2$ & $\begin{array}{l}1.3 \\
(1.5)\end{array}$ & $+(3)$ \\
\hline \multirow{2}{*}{$\begin{array}{l}21^{\circ} \mathrm{C} \text { in } \\
\text { darkness }\end{array}$} & 1 & 91.7 (12) & $52.9 \pm 26.6$ & 24.4 & $+(17)$ \\
\hline & 3 & $100.0 \quad(9)$ & $43.0 \pm 27.6$ & $\begin{array}{c}43.2 \\
(33.8)\end{array}$ & $+(7)$ \\
\hline $\begin{array}{l}\text { Temperature } \\
\text { shift from } \\
21^{\circ} \mathrm{C} \text { to } 25^{\circ} \mathrm{C}\end{array}$ & 1 & $100.0 \quad$ (5) & $19.6 \pm 11.3$ & 87.8 & n.c. \\
\hline \multirow{3}{*}{$\begin{array}{l}\text { Temperature } \\
\text { shift from } \\
21^{\circ} \mathrm{C} \text { to } 28^{\circ} \mathrm{C}\end{array}$} & 1 & $100.0 \quad(7)$ & $22.0 \pm 22.7$ & 81.8 & $-(8)$ \\
\hline & 2 & $66.6(24)$ & $19.0 \pm 32.5$ & 86.2 & $-(32)$ \\
\hline & 3 & $90.6(11)$ & $19.8 \pm 15.9$ & $\begin{array}{c}89.4 \\
(85.8)\end{array}$ & $-(2)$ \\
\hline \multirow[t]{2}{*}{$28^{\circ} \mathrm{C}$} & 2 & $0 \quad$ (23) & & & \\
\hline & 3 & $0 \quad$ (15) & & & \\
\hline
\end{tabular}

a) Mosquitoes were kept with 12 -hr light period except mosquitoes at $21^{\circ} \mathrm{C}$ in darkness.

b) Sporozoite infection was not checked. 
If the number could not be counted, all the supernatant was used for infection of a hamster. To examine infectivity of sporozoites, the final examination of parasitemia was carried out on day $14 \mathrm{PI}$.

Nourishing effect of feeding solutions of purified ookinetes on the sporogonic development:

A. stephensi was infected by membrane feeding of purified ookinetes $\left(1 \times 10^{6} / \mathrm{m} l\right)$ to study the essential nourishment of blood on sporogony of $P$. berghei. Phosphate buffered saline (PBS: $8.0 \mathrm{~g}$ of $\mathrm{NaCl}, 0.2 \mathrm{~g}$ of $\mathrm{KCl}, 1.15 \mathrm{~g}$ of $\mathrm{Na}_{2} \mathrm{HPO}_{4}$ and $0.2 \mathrm{~g}$ of $\mathrm{KH}_{2} \mathrm{PO}_{4}$ per litter) was used as non nourishment. Five per cent glucose and washing medium were used for feeding ookinetes as moderate nourishment. A experiment of mosquitoes infected with ookinetes in PBS and in 5\% glucose were maintained on $5 \%$ glucose in stead of $5 \%$ sucrose. Heparinized fresh hamster blood was diluted two times with washing medium and used for feeding ookinetes as blood meal (complete nourishment), because a small volume of whole blood easily evaporates during feeding and because it is too sticky for mosquitoes to engorge. $\mathrm{RBC}$ of heparinized hamster blood (1 volume) were washed once with cold PBS (100 volumes) and resuspended with PBS (1 volume) as RBC suspension.

To study the nourishing effect of blood component on sporogonic development of purified ookinetes, PBS was supplemented with each $10 \%$ of hamster RBC suspension, FBS as serum component and hamster whole blood. Each feeding solution was supplemented with $10 \mathrm{mM}$ of $\mathrm{NaHCO}_{3}$, a phagostimulant for anopheline mosquitoes (Galun et al., 1985; Yano et al., in preparation).

Feeding of ookinetes to mosquitoes:

Purified ookinetes were resuspended in 0.5 to $1.5 \mathrm{~m} l$ of each feeding solution to obtain the concentration $1 \times 10^{6}$ ookinetes per $\mathrm{m} l$.

Water-jacketed membrane feeders $(2.6 \mathrm{~cm}$ in an inside diameter) (Rutledge et al., 1964) fitted with a Baudruche membrane (Long and Long, Belleville, New Jersey) were used for

Table 2 Nourishing effect of feeding solution of purified Plasmodium berghei ookinetes on the sporogonic development

\begin{tabular}{|c|c|c|c|c|c|}
\hline $\begin{array}{l}\text { Feeding } \\
\text { solution }\end{array}$ & $\begin{array}{c}\text { Dissecting } \\
\text { time } \\
\text { (days) }\end{array}$ & $\begin{array}{c}\% \text { Infected } \\
\text { (No. examined) }\end{array}$ & $\begin{array}{l}\text { No. of oocysts/ } \\
\text { infected } \\
\text { mosquito } \pm \mathrm{SD}\end{array}$ & $\begin{array}{l}\text { Degeneration } \\
\text { rate }(\%)\end{array}$ & $\begin{array}{c}\text { Infectivity of } \\
\text { sporozoites }\end{array}$ \\
\hline $5 \%$ Glucose & $12-18$ & $12.1 \quad(33)$ & $1.3 \pm 0.5$ & 100.0 & n.c. ${ }^{\text {a) }}$ \\
\hline \multirow[t]{2}{*}{ PBS } & $8-10$ & $40.8 \quad(71)$ & $3.2 \pm 3.7$ & 4.3 & n.c. \\
\hline & $12-18$ & 44.1 (183) & $4.3 \pm 5.6$ & 19.0 & $4 / 5^{\mathrm{b})}$ \\
\hline \multirow{2}{*}{$\mathrm{PBS}+10 \% \mathrm{FBS}$} & $8-10$ & $68.4 \quad(19)$ & $18.9 \pm 20.8$ & 0 & n.c. \\
\hline & $12-18$ & $87.0 \quad(46)$ & $29.5 \pm 29.5$ & 18.6 & $2 / 2$ \\
\hline \multirow[t]{2}{*}{ Washing medium } & $8-10$ & $45.5 \quad$ (11) & $5.4 \pm 5.9$ & 0 & n.c. \\
\hline & $12-18$ & $76.3 \quad(76)$ & $6.9 \pm 6.8$ & 11.0 & $6 / 6$ \\
\hline \multirow[t]{2}{*}{ Blood meal } & $8-10$ & $92.3 \quad(26)$ & $42.5 \pm 41.1$ & 4.8 & n.c. \\
\hline & $12-18$ & 87.4 (143) & $31.6 \pm 34.7$ & 7.9 & $5 / 5$ \\
\hline
\end{tabular}

a) Sporozoite infection was not checked.

b) No. of infection/No. of trials. 
Table 3 Nourishing effect of blood component in the feeding solution of purified Plasmodium berghei ookinetes on the sporogonic development

\begin{tabular}{lccc}
\hline $\begin{array}{l}\text { Feeding } \\
\text { solution }\end{array}$ & $\begin{array}{c}\text { \% Infected } \\
\text { (No. examined })\end{array}$ & $\begin{array}{c}\text { No. of oocysts/ } \\
\left.\text { infected mosquito } \pm \mathrm{SD}^{\mathrm{a}}\right)\end{array}$ & $\begin{array}{c}\text { Degeneration } \\
\text { rate }(\%)\end{array}$ \\
\hline PBS+10\% FBS & $100.0(31)$ & $36.3 \pm 29.8$ & 17.6 \\
$\begin{array}{l}\text { PBS+10\% RBC } \\
\text { suspension }\end{array}$ & $95.7(23)$ & $25.8 \pm 35.6$ & 11.6 \\
$\begin{array}{l}\text { PBS+10\% Whole } \\
\text { blood }\end{array}$ & $100.0(29)$ & $34.2 \pm 27.4$ & 22.0 \\
Blood meal & $94.7(18)$ & $38.9 \pm 33.0$ & 12.9 \\
\hline
\end{tabular}

a) The presence of oocysts was examined on day $14 \mathrm{PI}$.

feeding. Feeders were pre-warmed at $37^{\circ} \mathrm{C}$ in a $21^{\circ} \mathrm{C}$-incubator. Mosquitoes in small cage were fed ookinetes in solution for $15 \mathrm{~min}$. From day 8-10 PI, and 12-18 PI, the dissected midguts were examined for the presence of oocysts. Sporozoite infection of hamsters was carried out by intracardial inoculation of day 14-18 PI as described before.

Degenerative rate of oocysts:

The degenerative changes of oocysts proceeded from a few granules observed in the protoplasm of an oocyst, to coarse granules that filled the whole protoplasm of an oocyst. Finally, the protoplasm with coarse granules shrunk away from the oocysts wall and concentrated in the oocyst as an amorphous mass. Oocysts which under phase-contrast microscopic examination contained distinct coarse granules were counted as degenerative oocysts. Degeneration rate of oocysts was caliculated from total degenerative oocysts per all oocysts of an experimental group.

\section{RESULTS}

Effects of environmental temperature and darkness on the development of malaria oocysts:

Table 1 summarizes the effects of environmental temperature and darkness on the development of malaria oocysts. The rate of infection and numbers of oocysts per mosquito did not differ significantly among mosquitoes kept at $21^{\circ} \mathrm{C}$ with $12-\mathrm{hr}$ light period $\left(21^{\circ} \mathrm{C}\right.$ mosquitoes), at $21^{\circ} \mathrm{C}$ in darkness, and of temperature shift from $21^{\circ} \mathrm{C}$ for $24 \mathrm{hr}$ to $25^{\circ} \mathrm{C}\left(21^{\circ} \mathrm{C}\right.$ to $25^{\circ} \mathrm{C}$ mosquitoes) or to $28^{\circ} \mathrm{C}\left(21^{\circ} \mathrm{C}\right.$ to $28^{\circ} \mathrm{C}$ mosquitoes). Almost all oocysts of $21^{\circ} \mathrm{C}$ mosquitoes matured without degenerative changes but the oocysts of $21^{\circ} \mathrm{C}$ mosquitoes in darkness, $21^{\circ} \mathrm{C}$ to $25^{\circ} \mathrm{C}$ mosquitoes and $21^{\circ} \mathrm{C}$ to $28^{\circ} \mathrm{C}$ mosquitoes degenerated significantly during their maturation; the average degeneration rates of oocysts were $33.8 \%, 87.8 \%$ and $85.8 \%$, respectively, in contrast to the $1.5 \%$ of $21^{\circ} \mathrm{C}$ mosquitoes. Infective sporozoites were recognized both in mosquitoes kept at $21^{\circ} \mathrm{C}$ with 12 -hr light period and those kept in darkness. Mosquitoes that were shifted from $21^{\circ} \mathrm{C}$ for $24 \mathrm{hr}$ to $25^{\circ} \mathrm{C}$ or $28^{\circ} \mathrm{C}$ could not develop mature oocysts with sporozoites. In none of the surviving mosquitoes kept at $28^{\circ} \mathrm{C}$ with 12 -hr light period could any development of oocysts be recognized in their midguts.

Nourishing effect of feeding solutions of purified ookinetes on the sporogonic development: 
Mosquitoes fed purified ookinetes in PBS developed infective sporozoites but the infective rate and the number of oocysts per mosquito were lower than those fed ookinetes in PBS supplemented with 10\% FBS, ookinetes in washing medium or in blood meal (Table 2). Addition of $10 \%$ FBS to PBS improved the infection rate, $40.8 \%$ in day $8-10 \mathrm{PI}$ and $44.1 \%$ in day $12-18$ PI to $68.4 \%$ and $87.0 \%$, respectively, and the number of oocysts per mosquito, $3.2 \pm$ 3.7 oocysts in day $8-10 \mathrm{PI}$ and $4.3 \pm 5.6$ oocysts in day $12-18$ PI to $18.9 \pm 20.8$ and $29.5 \pm 29.5$, respectively.

Changes of PBS $+10 \%$ FBS to washing medium $(\mathrm{F}-12+10 \%$ FBS $+25 \mathrm{mM}$ HEPES + $0.2 \% \mathrm{NaHCO}_{3}$ ) decreased the degenerative rate, from $18.6 \%$ to $11.0 \%$ but the infected rate was not significantly different. Mosquitoes fed ookinetes in blood meal had the highest infection rates, $92.3 \%$ on day $8-10 \mathrm{PI}$ and $87.4 \%$ on day $12-18 \mathrm{PI}$.

Young oocysts on day 8-10 PI of mosquitoes fed ookinetes in PBS with $10 \%$ FBS and washing medium did not degenerate but some later oocysts of mosquitoes fed ookinetes in all five kinds of solutions contained degenerative granules; the degenerative rates were $19.0 \%$ in PBS, $18.6 \%$ in PBS $+10 \%$ FBS, $11.0 \%$ in washing medium and $7.9 \%$ in blood meal.

The infection rate of mosquitoes fed ookinetes in $5 \%$ glucose was very low, $12.1 \%$ of 33 mosquitoes in two experiments. The number of oocysts per mosquito was $1.3 \pm 0.5$ and all oocysts were degenerated.

The addition of $10 \% \mathrm{RBC}$ suspension to PBS decreased the degenerative rate of oocysts as did the blood meal (Table 3).

The number of oocysts in mosquitoes fed ookinetes in PBS $+10 \%$ RBC suspension was the lowest, $25.8 \pm 35.6$ in contrast to $36.3 \pm 29.8$ in PBS $+10 \%$ FBS, $34.2 \pm 27.4$ in PBS $+10 \%$ whole blood and $38.9 \pm 33.0$ in blood meal, respectively.

\section{DISCUSSION}

The temperature range which permits $P$. berghei ookinete formation in the natural vector A. dureni, is $18^{\circ} \mathrm{C}$ to $21^{\circ} \mathrm{C}$ (Yoeli, 1965). In the experimental vector, $A$. stephensi, oocysts did not develop at $28^{\circ} \mathrm{C}$ (Table 1). When ookinetes were allowed to form at $21^{\circ} \mathrm{C}$ for $24 \mathrm{hr}$ after feeding parasitized blood, and then the environmental temperature was shifted to $25^{\circ} \mathrm{C}$ or $28^{\circ} \mathrm{C}$, A. stephensi could develop young oocysts at $25^{\circ} \mathrm{C}$ and $28^{\circ} \mathrm{C}$, but no mature oocysts formed at these temperatures.

Mosquitoes exposed to high temperature fail to develop sporozoites of $P$. berghei (Vanderberg and Yoeli, 1966). Thus the oocysts of $21^{\circ} \mathrm{C}$ to $25^{\circ} \mathrm{C}$ mosquitoes and $21^{\circ} \mathrm{C}$ to $28^{\circ} \mathrm{C}$ mosquitoes were highly degenerated during their later developmental stage. Oocysts without apparent degenerative changes were smaller and their development seemed to be retarded. Some had cloudy protoplasms with fine granules, indicating the start of degenerative changes. The damaging action of high temperature would begin before sporozoite budding, for there were no oocysts containing sporozoites.

In darkness, mosquitoes remained motionless in the cages. The degenerative changes of oocysts of $21^{\circ} \mathrm{C}$ mosquitoes in darkness were high. We assume that poor nourishment of mosquitoes, which did not feed on the $5 \%$ sugar solution in darkness was responsible for this finding. The transformation rate from ookinetes to oocysts increased in mosquitoes in darkness, compared to mosquitoes with 12-hr light period. We assume that the motionless of mosquitoes was responsible for this finding. 
Mosquitoes fed ookinetes in PBS could develop mature oocysts and infective sporozoites when they were provided solely $5 \%$ sugar or $5 \%$ glucose on cotton roll like avian malaria ookinetes (Rosenberg and Koontz, 1984) (Table 2). Blood components were not essential on the development from ookinete to sporozoite.

Mosquitoes fed ookinetes in 5\% glucose were seldom infected and they developed only a small number of degenerative oocysts per mosquito. The reason for this seems to be the weakly acidic glucose solution and its unstable $\mathrm{pH}$.

The serum component, FBS, supplemented with PBS improved the viability of ookinetes in membrane feeders, and increased infectivity and the number of oocysts per infected mosquitoes almost the same as blood meal. The ookinetes kept in PBS in an ice bath for 30 min lost significantly their infectivity to mosquitoes compared to ookinetes kept in washing medium that proved completely infective for mosquitoes (100\% infective rate). The RBC with PBS improved the viability of ookinetes to a lesser degree than FBS and whole blood (Table 3) but supplemented the nourishment and decreased the degeneration rate of developing oocysts.

The oocyst maturation in mosquitoes fed ookinetes in blood meal preceded by more than one day the maturation in mosquitoes fed ookinetes in PBS, PBS $+10 \%$ FBS and washing medium. The maturation of oocysts could explain the higher degeneration rate of oocysts in day 8-10 PI of mosquitoes fed ookinetes in blood meal, because the degenerative changes became dominant in late stages of oocysts.

There was a large difference between the degeneration rate of oocysts in mosquitoes fed directly by bite on an infected hamster $(1.5 \%)$ and those fed in vitro-formed ookinetes in blood meal (7.9\% in Table 2 and $12.9 \%$ in Table 3 ). The gametocytes acquired by mosquitoes by bite should transform to ookinetes within $20 \mathrm{hr}$ not to be trapped within the peritrophic membrane (Orihel, 1975). Thus ookinetes penetrating the peritrophic membrane to the midgut basement membrane would be biologically stronger than those transformed later and trapped within the peritrophic membrane, and could grow to mature oocysts and sporozoites without degeneration.

The ookinetes acquired by mosquitoes through membrane feeders could easily reach the midgut basement membrane before the peritrophic membrane hardened and had no selection of biological strongness. Some ookinetes could not retain the capacity for maturation due to unknown factors.

The experimental transformation of ookinetes to oocysts in vitro remained unsolved. The system of feeding purified ookinetes in simple chemical solution, PBS, would help to gain more information about it.

\section{ACKNOWLEDGEMENTS}

The authors wish to thank to Ms. Rebecca Shamy for technical assistance. This work was supported by Public Health Service research grant Al 18345 from the National Institute of Allergy and Infectious Diseases.

\section{REFERENCES}

1) Galun, R., Koontz, L.C. and Swadz, R.W. (1985): Engorgement response of anopheline 
mosquitoes to blood fractions and artificial solutions, Physiol. Entomol., 10, 145-149

2 ) Hollindale, M.R., Leland, P. and Schwartz, A.L. (1983): In vitro cultivation of the exoerythrocytic stage of Plasmodium berghei in a hepatoma cell line, Am. J. Trop. Med. Hyg., 32, 682-684

3 ) Janse, C.J., Mons, B., Croon, J.J.A.B. and Van der Kaay, H.J. (1984): Long-term in vitro culture of Plasmodium berghei and preliminary observations on gametocytogenesis, Int. J. Parasitol., 14, 317-320

4 ) Janse, C.J., Mons, B., Rouwenhorst, R. J., Van der Klooster, P.F.J., Overdulve, J.P. and Van der Kaay, H.J. (1985a): In vitro formation of ookinetes and functional maturity of Plasmodium berghei gametocytes, Parasitol., 91, 19-29

5 ) Janse, C.J., Mons, B., Rouwenhorst, R.J., Van der Klooster, P.F.J., Van der Kaay, H.J. and Overdulve, J.P. (1985b): Development of Plasmodium berghei ookinetes in the midgut of Anopheles atroparvus mosquitoes and in vitro, Parasitol., 91, 219-225

6 ) Mons, B., Janse, C.J., Boorsma, E.G. and Van der Kaay, H.J. (1985): Synchronized erythrocytic shizogony and gametocytogenesis in Plasmodium berghei in vivo and in vitro, Parasitol., 91, 423-430

7 ) Munderloh, U.G. and Kurtti, T.J. (1987): The infectivity and purification of cultured Plasmodium berghei ookinetes, J. Parasitol., 73, 919-923

8 ) Orihel, T.C. (1975): In "Invertebrate Immunity" (K. Maramorosch and R.E. Shope, eds.) pp. 65-73, Academic Press, New York

9 ) Rosenberg, R. and Koontz, L.C. (1984): Plasmodium gallinaceum: Erythrocyte factor essential for zygote infection of Aedes aegypti, Exp. Parasitol., 57, 158-164

10) Rutledge, L.C., Ward, R.A. and Gould, D.J. (1964): Studies on the feeding response of mosquitoes to nutritive solutions in a new membrane feeder, Mosquito News, 24, 407-419

11) Sinden, R.E., Hartley, R.H. and Wingor, L. (1985): The development of Plasmodium ookinetes in vitro: an ultrastructural study including a description of meiotic division, Parasitol., 91, 227-244

12) Vanderberg, J.P. and Yoeli, M. (1966): Effect of temperature on sporogonic development of Plasmodium berghei, J. Parasitol., 52, 559-564

13) Vanderberg, J.P., Nussenzweig, R.S. and Most, H. (1968): Further studies on the Plasmodium berghei-Anopheles stephensi-rodent system of mammalian malaria, J. Parasitol., 54, 1009-1016

14) Weiss, M.M. and Vanderberg, J.P. (1977): Studies on Plasmodium ookinetes: II. In vitro formation of Plasmodium berghei ookinetes, J. Parasitol., 63, 932-934

15) Yoeli, M. (1965): Studies on Plasmodium berghei in nature and under experimental conditions, Trans. R. Soc. trop. Med. Hyg., 59, 255-276 
Plasmodium berghei の sporogony について, 蚊の飼育温度と 純化 ookinete の発育に対する membrane feeding 液の影響

\author{
矢野 健一* ${ }^{*}$ K. Maramorosch $・$ A. Kozlowska
}

Plasmodium berghei (ANKA 株) 一シリアンハムスターーAnopheles stephensi の系を使用し た。P. berghei 感染ハムスターを吸血した A. stephensi での ookinete 形成には, 蚊の飼育温度を $21^{\circ} \mathrm{C}$ 保つことが必須条件であった。吸血蚊を $21^{\circ} \mathrm{C}$ 暗闇に保つと oocyst 形成は増えたが, oocyst の発育中に $33.8 \%$ が変性を起こした。吸血後, A. stephensi を通常の飼育温度 $28^{\circ} \mathrm{C} て ゙$ 飼育 すると oocyst の形成は全く見られなかったが, 吸血後 24 時間 $21^{\circ} \mathrm{C} に$ 保った後 $28^{\circ} \mathrm{C} て ゙$ 飼育したもの では，oocyst の発育は見られたが，sporozoiteへの発育は阻害された。

P. berghei 感染八ムスター血を，10\% FBS， 25 mM Bicine 加 Ham's F-12 培地（pH 8.0）で 約 $10 \%$ に希釈し， $21^{\circ} \mathrm{C} て ゙ 22-24$ 時間培養し，ookinete を得た。Percoll gradient (0〜36\%〜 45\%) で純化した ookinete $\left(1 \times 10^{6} / \mathrm{m} l\right)$ を，5\%グルコース，PBS，PBS-10\% FBS，F-12-10\% FBS，八ムスター全血に再浮遊し， membrane feeding 法で蚊に感染させた。血液成分を使用し なくても，PBSを feeding 液として ookinete を蚊に感染させた後，5％蔗糖あるいは $5 \%$ グル コースで飼育して, 感染力のある sporozoite を得た。その場合の低い感染率 (44.1\%), oocyst 数 (4.3個) は, PBSに $10 \%$ FBS を添加することにより感染率 (87.0\%), oocyst 数 (29.5個) と を, 全血を feeding 液に使用した場合とほぼ同じ程度に回復させ得た。赤血球を全血の $10 \%, \mathrm{PBS}$ に添加した場合は, FBS 添加より感染率, oocyst 数は劣ったが, oocyst の変性率は低下した。FBS 添加による感染率, oocyst 数の回復効果は, oocyst 発育過程での栄養供給よりも, membrane feeding 中の ookinete の viability の低下を防ぐ為と思われる。赤血球には, oocyst 発育過程での 栄養供給効果があると思われ，oocyst の変性率を低下させた。

Department of Entomology and Economic Zoology, Cook College, Rutgers University

*現所属：大阪大学微生物病研究所原虫学部門 